Article

\title{
Is the Board of Directors' Religion Related to Tax Avoidance? Empirical Evidence in South Korea
}

\author{
Hyeong Tae Cho ${ }^{1}$ and Sung Man Yoon ${ }^{2, * * 1}$ \\ 1 College of Business Administration, Hongik University, Seoul 04066, Korea; cht1212@hongik.ac.kr \\ 2 Department of Business Administration, Seoul National University of Science and Technology, \\ Seoul 01811, Korea \\ * Correspondence: ysm6123@seoultech.ac.kr
}

Received: 29 July 2020; Accepted: 9 October 2020; Published: 13 October 2020

check for updates

\begin{abstract}
This study investigates the effect of directors' religious diversity on tax avoidance of firms. The board of directors plays an important role in supervising the management of the corporation. As such, the religious diversity of the board may affect corporate decisions and their implementation by the management. In this regard, this study analyzes the effect of the religious diversity of the directors on the level of tax avoidance. Results are presented as follows. First, the level of tax avoidance tends to be higher when the level of religious diversity among the board members is high. Second, tax avoidance level may be different depending on a CEO's religion, holding that the religions of board members are diverse. Third, the tax avoidance activity of a corporation is likely to be discouraged if the religions of board members are converged into a single religion. Overall, the results of this study provide an implication that religious factors influence the level of the firm's tax avoidance.
\end{abstract}

Keywords: religion; tax avoidance; board of directors; Buddhism; Catholic; Protestantism

\section{Introduction}

In recent years, companies are increasingly interested in the diversity of the composition of employees and exert efforts to secure excellent talent regardless of gender, race, and nationality among multinational companies (Shehata et al. 2017). Although the increase in diversity may cause conflict because of heterogeneous race, emotion, and culture, companies can improve their performance by discovering new markets and business opportunities, creating ideas, accommodating social needs for minority care, and securing outstanding employees (Jeon et al. 2017).

In particular, the diversity of the composition of the board of directors (BOD) has recently attracted considerable attention because many studies conclude BOD diversity has a positive effect on the strategic decision making of a corporation from various perspectives (Hernández-Nicolás et al. 2019). Thus, one may expect that the intrinsic function of the BOD, which plays an efficient monitoring and advising role, will be improved by including diverse members in the BOD.

Furthermore, previous studies on religion and tax avoidance or tax consciousness have shown that the probability of tax avoidance is lower if the level of religion is higher (Gupta and McGee 2010; Jun and Yoon 2018). Ross and McGee (2011) also presented empirical evidence that the tendency for tax evasion or avoidance is lower if the frequency of participation in religion is higher. Therefore, we can expect the religious diversity of BOD members is related to the corporation's tax avoidance activity based on the findings of these studies.

Therefore, this study aims to investigate the effect of the religious diversity of BOD members on corporate tax avoidance by expanding the diversity of the BOD from a religious perspective. 
The remainder of the work is organized as follows. Section 2 provides a review of prior literature on the role of the director board and tax avoidance. Section 3 presents research questions, research model, and sample selection as an empirical research design. Section 4 shows the results of descriptive statistics, correlation, and regression analysis. Lastly, Section 5 summarizes the results of the study and provides the conclusions.

\section{Literature Review and Hypothesis}

\subsection{Literature on the Role of the Director Board}

The main roles of the corporate governance are to monitor the opportunistic behavior of the management and reduce agency costs by aligning the interests of the management and the external stakeholders (Charreaux and Desbrières 1998). Thus, a sound corporate governance improves the earning quality and increases value of shares in a company ultimately by reducing the opportunistic behavior of the management (Bhagat and Bolton 2008; Chen et al. 2009).

One of the responsibilities of the BOD is to provide an oversight of the management's decision making and financial reports (Matten and Crane 2005). Prior studies on the BOD have mainly focused on its composition and characteristics and analyzed its features, such as independence, professionalism, and meeting frequency. Furthermore, the studies examined whether the features of the BOD affect the corporation's financial reporting, including accounting quality and financial fraud. Some of the studies provided evidence that the lack of independence of the BOD increases the incidence of discretionary accrual and accounting fraud (Dechow et al. 1996; Beasley 1996; Klein 2002). Other studies showed that discretionary accrual would be reduced if the BOD has a financial expert member and if the board meeting frequency is high (Xie et al. 2003). In South Korea, studies on the BOD presented empirical results that the extent of upward income adjustment was mitigated if the independence of the outside director is higher; moreover, the value relevance of the BOD to accounting quality and accounting conservatism are higher if the independence, expertise, and mobility of outside directors are higher (Kim 2006; Kim and Bae 2007). As mentioned previously, a considerable number of previous studies provide consistent evidence that independence, professionalism, and the active role of the BOD contribute to the reduction of earnings management by reducing discretionary accruals.

Recently, researchers have paid more attention to BOD diversity, which may enhance BOD independence and affect the strategic decision making in a corporation positively (Bhagat and Bolton 2008). Corporations are more likely to increase the BOD diversity with diverse demographics, including gender, age, education, and work experience. The diversity of the BOD can be perceived by either using observable or non-observable factors. The observable factors include board members' demographic characteristics, such as gender, race, and age, whereas the non-observable factors include board members' knowledge, personality, and work experience. Previous studies relating to the diversity of the BOD mainly deals with gender, which is an observable factor for determining BOD diversity. According to studies, the performance of a corporation is remarkable if the female board members are independent and if a corporation has several female board members. Moreover, based on prior research, the presence of a female BOD member provides an additional monitoring function on the management where corporate governance is weak; in particular, the BOD monitors the management more efficiently if a female member is appointed in an audit committee (Carter et al. 2003; Adams and Ferreira 2009; Gul et al. 2011). Other studies that include background and nationality diversity are related to BOD diversity.

Recently, many companies aggressively appoint retired politicians as outside directors, because they have the potential to connect companies closely to government departments linked to the company's business by utilizing their work experience and existing networking with the departments (Fan et al. 2007; Wu et al. 2012). A considerable number of South Korea's large corporations have outside directors who are ex-government officials, and some studies show that the presence of outside directors help the corporations to receive government subsidies or funds from the capital market more 
easily. In addition, the performance of corporates with those outside directors is found to be better (Goldman et al. 2009; Wang 2015).

As discussed previously, BOD diversity affects corporate management or performance significantly. In this regard, the government practically regulates companies to drive them to achieve a certain level of BOD diversity.

\subsection{Literature on Tax Avoidance}

The tax avoidance incentives of a corporation are determined by various factors, including the agency costs incurred in the relationship between shareholders and managers, the risk that arises when tax authorities detect tax avoidance, and the reputation expense incurred between the corporation and the general public (Choi 2018).

Given that the information asymmetry between shareholders and managers in corporate management is highly likely, the agency cost that relates to tax avoidance that arises as the optimal tax avoidance measure from the standpoint of shareholders may be different from the measures for corporate managers. Tax avoidance may increase corporate value but can also be a risky investment (Rego and Wilson 2012). For example, a risk-averse manager may select tax avoidance measures that are short for accommodation of the risk appetite of the risk-neutral shareholders and may lead to under investment in tax avoidance.

In addition, the agency costs regarding tax avoidance may be incurred because of the manager's personal attributes. Desai et al. (2007) showed that opportunistic managers structured complex transactions to facilitate the use of saved taxes for personal interest. Law and Mills (2017) showed that managers with military experience pursue less tax avoidance than other managers.

In this regard, corporate governance is designed to reduce these agency costs by designing executive compensation, ownership structure, institutional investors, and the BOD. In particular, the BOD is an important body to control managers as the BOD approves corporate decisions and provides oversight on corporate management. Armstrong et al. (2015) assumed an optimal level of tax avoidance for each corporation and provided empirical evidence that a corporation pursues tax avoidance until it reaches the optimal level, because net benefits from tax avoidance are positively correlated to corporate value. However, the corporation discontinues its pursuit of tax avoidance when marginal costs exceed marginal benefits. According to Armstrong et al. (2015), tax avoidance was positively correlated to the independence and expertise of the BOD at a low level of tax avoidance and negatively correlated at a high level of tax avoidance. Accordingly, they indicate that a sound corporate governance prevents extreme tax avoidance attempts rather than simply increasing (or decreasing) tax avoidance activity in one direction.

\subsection{Hypothesis Development}

Based on prior studies on corporate tax avoidance, the characteristics of the BOD, including diversity, is expected to affect the corporate behavior of the management on tax avoidance. Furthermore, BOD diversity may affect the corporate management to enhance its performance. Therefore, BOD diversity is likely to steer the corporate management to manage a firm to an optimum level of tax avoidance.

However, it is questionable how a corporate's tax avoidance would be if the BOD is diverse in terms of members' religions. Based on prior literature on corporate tax avoidance, the religious diversity in the BOD may increase or decrease the corporate tax avoidance level to reach an optimal level of tax avoidance in a way that BOD diversity enhances the corporation's performance. However, some prior literature on religion argues that the high level of individual religion may lead to the lower probability of individual tax avoidance (Gupta and McGee 2010; Jun and Yoon 2018). Accordingly, from this standpoint, the diverse religion of the BOD may decrease the corporate taxpayer's tax morale and increase their tax avoidance when religious diversity may be an obstacle to the religiosity of each individual board member. 
In this regard, we set out a hypothesis in a null hypothesis form to test the effect of religious diversity of the BOD on corporate tax avoidance.

Hypothesis 1. The religious diversity of the BOD does not affect corporate tax avoidance.

This study is distinguished from prior literature in such a way that no prior studies have reviewed the relationship of the religious diversity of the BOD with corporate tax avoidance. Previous studies on BOD diversity have limitations. For instance, religious diversity in BOD has not been addressed even though it constitutes either the observable or non-observable factors to determine BOD diversity. Religion may be a foundation for personal beliefs or moral values. Therefore, religious factors are expected to affect the function of the BOD greatly, which monitors or supervises during the management's decision making process. To the best of our knowledge, this study is the first piece of research to provide empirical evidence on whether the religious diversity of the BOD affects corporate tax avoidance activity.

\section{Research Methodologies and Data}

\subsection{Research Methodologies}

This study designs a research model (Equation (1)) to analyze the effect of the religious diversity of the board members on corporate tax avoidance. The dependent variable is a tax avoidance variable (TAX AVOID) (Desai and Dharmapala 2006), and the main independent variable of interest is the religious diversity in the BOD (DIVERSITY) determined by the standard deviation of the religion type of the board members. If the coefficient of the independent variable (DIVERSITY) is positive (+), then the religious diversity of the BOD may facilitate the company's tax avoidance. However, if the sign is negative (-), then the board's religious diversity is interpreted to discourage the company's tax avoidance.

Control variables are included to account for firm size (SIZE), the debt to equity ratio (LEV), return on assets (ROA), cash flow from operating activities (CFO), growth rate of number of employees (EMP), sales for export divided total sales (EXPORT), large shareholder ownership (LARGE), and audit quality (BIG4). These variables represent factors to affect corporate tax avoidance and are used in various prior studies on tax avoidance. In addition, a robustness check is needed using the Heckman two-stage model to address an endogeneity problem.

$$
\begin{gathered}
\text { TAX AVOID }=\alpha_{0}+\beta_{1} \text { DIVERSITY }+\left(\gamma_{1} \text { DIVERSITY X BUDDHISM }+\gamma_{2}\right. \text { DIVERSITY X } \\
\begin{array}{r}
\text { CATHOLIC } \left.+\gamma_{3} D I V E R S I T Y X \text { PROTESTANTISM }\right)+\beta_{2} \text { SIZE }+\beta_{3} L E V+\beta_{4} R O A+\beta_{5} C F O \\
+\beta_{6} E M P+\beta_{7} \text { EXPORT }+\beta_{8} L A R G E+\beta_{9} B I G 4+\Sigma Y E A R+\Sigma I N D+\varepsilon
\end{array}
\end{gathered}
$$

where,

TAX AVOID: The discretionary book-tax difference (BTD) is as used in Desai and Dharmapala (2006), similar to Equation (2). It is the residual from the regression model, where BTD is regressed on total accruals (TA). This is BTD after controlling for discretionary accruals used for earnings management purposes. TA corresponds to total accruals (net income minus operating cash flow) scaled by the beginning-of-the-year total assets. The greater value of discretionary BTD corresponds to a higher level of tax avoidance.

$$
B T D=\alpha_{1} T A+\varepsilon
$$

DIVERSITY: The standard deviation of the religion type of the board members (measured by standard deviation of the number of executives that belong to each of the six religions, including Buddhism, Catholicism, Confucianism, Protestantism, Unification Church, and Won Buddhism.)

BUDDHISM: 1 if the CEO's religion is Buddhism, 0 if otherwise.

CATHOLIC: 1 if the CEO's religion is Catholic, 0 if otherwise. 
PROTESTANTISM: 1 if the CEO's religion is Protestantism, 0 if otherwise.

SIZE: Natural log of total assets.

LEV: Leverage, measured as total debt divided by equity.

ROA: Net income divided by total assets at the beginning of the year.

CFO: Cash flow from operating activities divided by total assets.

EMP: Growth rate of employed workers.

EXPORT: Sales for export divided total sales for the year.

LARGE: Largest shareholder's ownership percentage

BIG4: 1 if a company is audited by a large accounting firm called Big4, 0 if otherwise.

YEAR $=$ Year dummy.

IND = Industry dummy.

\subsection{Data}

We obtained the financial data from KIS-VALUE, which is an authoritative financial database in South Korea. With respect to the religion of the board members, we collected the information from the Executive Directory published by KOSDAQ Listed Companies Association. This association disclosed the religions of the board members in the KOSDAQ listed firms through the Executive Directory until 2011.

The final sample consists of 1935 firm-year observations for the period of 2008 to 2011 that meet the following conditions:

- $\quad$ Listed firms in the KOSDAQ (excluding financial institutions);

- Firms with no deficit equity;

- Firms whose financial data are available;

- Firms where religions of directors are disclosed.

\section{Results}

\subsection{Descriptive Statistics and Correlation Analysis}

Table 1 illustrates the variables' descriptive statistics. TAX AVOID, a dependent variable that represents the level of corporate tax avoidance, shows an average of -0.020 with a range of -13.646 to 0.457 . DIVERSITY, a main independent variable, shows an average of 0.357 with a range of 0 to 1 . Protestantism takes $51.8 \%$ of the total sample. Buddhism and Catholicism account for $24.6 \%$ and $19.2 \%$ of total sample, respectively.

Table 1. Descriptive statistics $(n=1935)$.

\begin{tabular}{cccccc}
\hline & Mean & St. Dev & Min & Median & Max \\
\hline TAX AVOID & -0.020 & 0.476 & -13.646 & 0.0032 & 0.457 \\
DIVERSITY & 0.357 & 0.5817 & 0 & 0.361 & 1 \\
BUDDHISM & 0.246 & 0.336 & 0 & 0 & 1 \\
CATHOLIC & 0.192 & 0.309 & 0 & 0 & 1 \\
PROTESTANTISM & 0.518 & 0.456 & 0 & 1 & 1 \\
SIZE & 25.076 & 0.803 & 20.011 & 25.0104 & 28.021 \\
LEV & 0.569 & 2.780 & 0.003 & 0.4348 & 84.478 \\
ROA & 0.028 & 0.344 & -4.927 & 0.0322 & 11.546 \\
CFO & 0.060 & 0.288 & -2.048 & 0.0491 & 10.041 \\
EMP & 10.807 & 95.467 & -99.010 & 3.4200 & 2.510 \\
EXPORT & 26.721 & 31.047 & 0 & 12.6976 & 100 \\
LARGE & 33.638 & 18.432 & 0 & 33.010 & 87.900 \\
BIG4 & 0.427 & 0.495 & 0 & 0 & 1 \\
\hline
\end{tabular}

Note: The definitions of variables are the same as the measurement of variables in Equation (1). 
SIZE, a control variable that represents firm size, has an average of 25.076. LEV, a control variable that represents the firm's financial leverage, has an average of 0.569 . The average ROA and CFO are 0.028 and 0.060 , respectively. EMP shows an average of 10.807, indicating that companies in the sample increase their employment by more than $10 \%$ annually. The average EXPORT and LARGE are 26.721 and 33.638 , respectively. BIG4 has an average of 0.427 , suggesting that $42.7 \%$ of the sample firms have been audited by big accounting firms.

Table 2 presents the Pearson correlations between the variables used in these analyses. DIVERSITY has an insignificant correlation coefficient of 0.0239 with TAX AVOID. This finding suggests that no statistically significant relation was observed between the religious diversity of the BOD and tax avoidance. However, considering that the correlation coefficient is positive, the religious diversity of the BOD may have a positive relationship with corporate tax avoidance at an insignificant level.

Table 2. Correlation analysis.

\begin{tabular}{|c|c|c|c|c|c|c|}
\hline & (1) & (2) & (3) & (4) & (5) & (6) \\
\hline (1) TAX AVOID & 1 & & & & & \\
\hline (2) DIVERSITY & $\begin{array}{c}0.0239 \\
(0.4564) \\
\end{array}$ & 1 & & & & \\
\hline (3) BUDDHISM & $\begin{array}{c}-0.0784^{* *} \\
(0.0145)\end{array}$ & $\begin{array}{c}-0.0954^{* * *} \\
(0.0001)\end{array}$ & 1 & & & \\
\hline (4) CATHOLIC & $\begin{array}{c}0.0092 \\
(0.7746) \\
\end{array}$ & $\begin{array}{c}-0.1380^{* * *} \\
(0.0001)\end{array}$ & $\begin{array}{c}-0.1336^{* * *} \\
(0.0001)\end{array}$ & 1 & & \\
\hline (5) PROTESTANTISM & $\begin{array}{c}0.0115 \\
(0.7197)\end{array}$ & $\begin{array}{c}-0.1386^{* * *} \\
(0.0001)\end{array}$ & $\begin{array}{c}-0.2489 * * * \\
(0.0001)\end{array}$ & $\begin{array}{c}-0.2231 \text { *** } \\
(0.0001)\end{array}$ & 1 & \\
\hline (6) SIZE & $\begin{array}{l}-0.0225 \\
(0.4835) \\
\end{array}$ & $\begin{array}{c}0.0735^{* * *} \\
(0.0041)\end{array}$ & $\begin{array}{c}0.0214 \\
(0.4042) \\
\end{array}$ & $\begin{array}{l}-0.0159 \\
(0.5340)\end{array}$ & $\begin{array}{l}-0.0241 \\
(0.3474)\end{array}$ & 1 \\
\hline (7) LEV & $\begin{array}{c}-0.9148^{* * *} \\
(0.0001)\end{array}$ & $\begin{array}{l}-0.0294 \\
(0.2513)\end{array}$ & $\begin{array}{c}0.0485 \\
(0.0581)\end{array}$ & $\begin{array}{l}-0.0046 \\
(0.8585) \\
\end{array}$ & $\begin{array}{l}-0.0296 \\
(0.2474)\end{array}$ & $\begin{array}{c}0.0835^{* * *} \\
(0.0011)\end{array}$ \\
\hline (8) $\mathrm{ROA}$ & $\begin{array}{c}-0.6785^{* * *} \\
(0.0001)\end{array}$ & $\begin{array}{l}-0.0166 \\
(0.5165)\end{array}$ & $\begin{array}{l}0.0630^{*} \\
(0.0139)\end{array}$ & $\begin{array}{l}-0.0213 \\
(0.4068)\end{array}$ & $\begin{array}{l}-0.0085 \\
(0.7403)\end{array}$ & $\begin{array}{c}0.0078 \\
(0.7600)\end{array}$ \\
\hline (9) $\mathrm{CFO}$ & $\begin{array}{c}-0.7140^{* * *} \\
(0.0001) \\
\end{array}$ & $\begin{array}{l}-0.0383 \\
(0.1347) \\
\end{array}$ & $\begin{array}{l}0.0444^{*} \\
(0.0832)\end{array}$ & $\begin{array}{l}-0.0042 \\
(0.8710) \\
\end{array}$ & $\begin{array}{l}-0.0174 \\
(0.4979) \\
\end{array}$ & $\begin{array}{c}0.0045 \\
(0.8604) \\
\end{array}$ \\
\hline (10) EMP & $\begin{array}{c}0.0417 \\
(0.2018)\end{array}$ & $\begin{array}{c}0.006 \\
(0.8199)\end{array}$ & $\begin{array}{l}-0.0208 \\
(0.4267)\end{array}$ & $\begin{array}{l}-0.0030 \\
(0.9094)\end{array}$ & $\begin{array}{c}0.0232 \\
(0.3755)\end{array}$ & $\begin{array}{c}0.0925^{* * *} \\
(0.0004)\end{array}$ \\
\hline (11) EXPORT & $\begin{array}{c}-0.0769^{* *} \\
(0.0173)\end{array}$ & $\begin{array}{l}-0.0212 \\
(0.4090) \\
\end{array}$ & $\begin{array}{c}0.0088 \\
(0.7332) \\
\end{array}$ & $\begin{array}{c}0.0819 * * * \\
(0.0014)\end{array}$ & $\begin{array}{c}0.0207 \\
(0.4220)\end{array}$ & $\begin{array}{c}0.1104^{* * *} \\
(0.0001)\end{array}$ \\
\hline (12) LARGE & $\begin{array}{c}-0.1166^{* *} \\
(0.0306)\end{array}$ & $\begin{array}{c}0.0422 \\
(0.3094)\end{array}$ & $\begin{array}{c}0.1007^{* *} \\
(0.0151)\end{array}$ & $\begin{array}{c}0.013 \\
(0.7545)\end{array}$ & $\begin{array}{c}0.0091 \\
(0.8274)\end{array}$ & $\begin{array}{c}0.0369 \\
(0.3743)\end{array}$ \\
\hline \multirow[t]{2}{*}{ (13) BIG4 } & $\begin{array}{c}0.0199 \\
(0.5359) \\
\end{array}$ & $\begin{array}{c}0.0281 \\
(0.2712) \\
\end{array}$ & $\begin{array}{c}0.0502 * * \\
(0.0494) \\
\end{array}$ & $\begin{array}{l}-0.0150 \\
(0.5583) \\
\end{array}$ & $\begin{array}{c}0.0257 \\
(0.3153) \\
\end{array}$ & $\begin{array}{c}0.1212 * * * \\
(0.0001) \\
\end{array}$ \\
\hline & (7) & (8) & (9) & (10) & (11) & (12) \\
\hline (8) ROA & $\begin{array}{c}0.4217^{* * *} \\
(0.0001)\end{array}$ & & & & & \\
\hline (9) $\mathrm{CFO}$ & $\begin{array}{c}0.5685^{* * *} \\
(0.0001)\end{array}$ & $\begin{array}{c}0.8851 \text { *** } \\
(0.0001)\end{array}$ & & & & \\
\hline (10) EMP & $\begin{array}{l}-0.0066 \\
(0.7999) \\
\end{array}$ & $\begin{array}{l}-0.0070 \\
(0.7900)\end{array}$ & $\begin{array}{c}0.0027 \\
(0.9174)\end{array}$ & & & \\
\hline (11) EXPORT & $\begin{array}{c}0.0904^{* * *} \\
(0.0004)\end{array}$ & $\begin{array}{c}0.0413 \\
(0.1085)\end{array}$ & $\begin{array}{c}0.0693^{* * *} \\
(0.0071)\end{array}$ & $\begin{array}{l}-0.0194 \\
(0.4608)\end{array}$ & & \\
\hline (12) LARGE & $\begin{array}{l}0.0722 * \\
(0.0819)\end{array}$ & $\begin{array}{c}0.028 \\
(0.5006)\end{array}$ & $\begin{array}{l}-0.0163 \\
(0.6946)\end{array}$ & $\begin{array}{l}-0.0046 \\
(0.9131)\end{array}$ & $\begin{array}{l}-0.0169 \\
(0.6841)\end{array}$ & \\
\hline (13) BIG4 & $\begin{array}{c}0.0043 \\
(0.8680)\end{array}$ & $\begin{array}{l}-0.0156 \\
(0.5435)\end{array}$ & $\begin{array}{c}0.0063 \\
(0.8068)\end{array}$ & $\begin{array}{l}-0.0124 \\
(0.6364)\end{array}$ & $\begin{array}{c}0.0086 \\
(0.7383)\end{array}$ & $\begin{array}{l}0.0283 \\
(0.496)\end{array}$ \\
\hline
\end{tabular}

Note $1:{ }^{*}, * *$, and ${ }^{* * *}$ indicate significance at the $10 \%, 5 \%$, and $1 \%$ levels, respectively, for a two-tailed test. Note 2 : The definitions of variables are the same as the measurement of variables in Equation (1). 
With respect to the relation between religion type and tax avoidance, BUDDHISM has a correlation coefficient of -0.0784 with TAX AVOID at a significant level $(p<0.05)$, whereas CATHOLIC and PROTESTANTISM have insignificant coefficients (0.0092 and 0.0115, respectively) with TAX AVOID. This finding implies that tax avoidance is less likely to occur in a company where the CEO's religion is Buddhism. However, tax avoidance has no relations with CEO's religion at a significant level in a company where the CEO's religion is Catholic or Protestant.

LEV and ROA have correlation coefficients of $-0.9148(p<0.01)$ and $-0.6785(p<0.01)$ with TAX AVOID, respectively, indicating that firms with high financial leverage or high ROA are less likely to be engaged in tax avoidance at a significant level. CFO, EXPORT, and LARGE have correlation coefficients of $-0.7140(p<0.01),-0.0769(p<0.05)$, and $-0.1166(p<0.05)$, respectively.

\subsection{Results of Regression}

Table 3 shows the test results on whether the religious diversity of the BOD affects corporate tax avoidance. As presented in the No Interaction column of Table 3, DIVERSITY has a statistically significant coefficient of $0.0049(p<0.1)$, indicating that if the BOD is composed of diverse directors in terms of religion, then the level of corporate tax avoidance is higher. This finding provides empirical implications that the religious diversity of the BOD may reduce tax avoidance. In other words, the management's tax avoidance may be discouraged in a corporation where the religions of board members are less diverse and more converged.

Table 3. The effect of directors' religious diversity on tax avoidance of firms.

\begin{tabular}{|c|c|c|c|c|}
\hline \multicolumn{5}{|c|}{$\begin{array}{r}\text { TAX AVOID }=\alpha_{0}+\beta_{1} \text { DIVERSITY }+\left(\gamma_{1} \text { DIVERSITY X BUDDHISM }+\gamma_{2} D I V E\right. \\
+\gamma_{3} \text { DIVERSITY X PROTESTANTISM }+\beta_{2} \text { SIZE }+\beta_{3} L E V+\beta_{4} R O A+\beta_{5} \\
+\beta_{7} \text { EXPORT }+\beta_{8} L A R G E+\beta_{9} B I G 4+Y E A R+I N D+\varepsilon\end{array}$} \\
\hline & \multicolumn{2}{|c|}{ No Interaction } & \multicolumn{2}{|c|}{ Interaction } \\
\hline & Coeff. & $t$-stat. & Coeff. & $t$-stat. \\
\hline DIVERSITY & 0.0049 * & 1.73 & $0.0068 *$ & 1.69 \\
\hline DIVERSITYXBUDDHISM & & & $-0.0257^{* * *}$ & -2.71 \\
\hline DIVERSITYXCATHOLIC & & & -0.0063 & -0.48 \\
\hline DIVERSITYXPROTESTANTISM & & & 0.0057 & 0.84 \\
\hline SIZE & $0.0102 *$ & 2.01 & $0.0099 *$ & 1.98 \\
\hline LEV & $-0.0587^{* * *}$ & -20.66 & $-0.0583 * * *$ & -20.76 \\
\hline ROA & $-0.1496^{* * *}$ & -4.12 & $-0.1437^{* * *}$ & -3.99 \\
\hline $\mathrm{CFO}$ & $0.7251^{* * *}$ & 24.49 & $0.7218^{* * *}$ & 24.62 \\
\hline EMP & -0.0002 & -0.98 & -0.0001 & -0.69 \\
\hline EXPORT & 0.0001 & 0.97 & 0.0001 & 1.05 \\
\hline LARGE & -0.0003 & -1.64 & $-0.0004^{* *}$ & -1.97 \\
\hline BIG4 & -0.0012 & -0.15 & 0.0007 & 0.09 \\
\hline$\Sigma$ YEAR & \multicolumn{2}{|c|}{ Included } & \multicolumn{2}{|c|}{ Included } \\
\hline$\Sigma I N D$ & \multicolumn{2}{|c|}{ Included } & \multicolumn{2}{|c|}{ Included } \\
\hline _cons & $-0.2642 *$ & -2.09 & $-0.2585^{* *}$ & -2.06 \\
\hline Obs. & \multicolumn{4}{|c|}{1935} \\
\hline F-stat. & \multicolumn{2}{|c|}{$609.12^{* * *}$} & \multicolumn{2}{|c|}{$468.57^{* * *}$} \\
\hline Adj. $R^{2}$ & \multicolumn{2}{|c|}{0.9428} & \multicolumn{2}{|c|}{0.9441} \\
\hline
\end{tabular}

Note $1:{ }^{*}, * *$, and ${ }^{* * *}$ indicate significance at the $10 \%, 5 \%$, and $1 \%$ levels, respectively, for a two-tailed. Note $2:$ The definitions of variables are the same as the measurement of variables in Equation (1).

As presented in the Interaction column of Table 3, this test result continues to be held even when interaction variables are added in the test model. The Interaction column of Table 3 shows that DIVERSITY has a statistically significant coefficient of $0.0068(p<0.1)$ in the model where the interaction variables of each type of CEO's religion are added. Meanwhile, the interaction variable of DIVERSITY and BUDDHISM has a statistically significant coefficient of $-0.0257(p<0.01)$ unlike 
other interaction terms of other religion types. This finding may imply that tax avoidance is more likely to happen in a company wherein the religions of the board members are diverse. However, this phenomenon would be less likely to occur if the CEO's religion is Buddhism. In other words, holding that the religions of the board members are diverse, tax avoidance may be less pursued in a corporation whose CEO's religion is Buddhism.

Control variables SIZE and CFO have statistically significant positive coefficients, implying that a corporation with larger size or higher cash flow from operations is likely to be engaged in more tax avoidance activities. Control variables LEV and ROA have negative relations with TAX AVOID at a statistically significant level. This finding suggests that firms with higher financial leverage or higher ROA may be engaged in less tax avoidance activities.

Table 4 presents test results of whether corporate tax avoidance is affected by the religion diversity of the BOD and CEO's religion of either Buddhism, Catholicism, or Protestantism.

Table 4. The effects of directors' religious diversity and CEOs' religion on tax avoidance of firms.

\begin{tabular}{|c|c|c|c|c|c|c|}
\hline \multicolumn{7}{|c|}{$\begin{array}{c}\text { TAX AVOID }=\alpha_{0}+\beta_{1} \text { DIVERSITY }+\left(\gamma_{1} \text { DIVERSITY X BUDDHISM }+\gamma_{2} \text { DIVERSITY X CATHOLIC }\right. \\
\left.+\gamma_{3} \text { DIVERSITY X PROTESTANTISM }\right)+\beta_{2} S I Z E+\beta_{3} L E V+\beta_{4} R O A+\beta_{5} C F O+\beta_{6} \text { EMP } \\
+\beta_{7} \text { EXPORT }+\beta_{8} L A R G E+\beta_{9} B I G 4+Y E A R+I N D+\varepsilon\end{array}$} \\
\hline & \multicolumn{2}{|c|}{ Buddhism } & \multicolumn{2}{|c|}{ Catholic } & \multicolumn{2}{|c|}{ Protestantism } \\
\hline & Coeff. & $t$-stat. & Coeff. & $t$-stat. & Coeff. & $t$-stat. \\
\hline DIVERSITY & $0.0083^{* * *}$ & 2.75 & $0.0051 *$ & 1.73 & $0.0015 *$ & 1.85 \\
\hline DIVERSITYXBUDDHISM & $-0.0272 * * *$ & -3.07 & & & & \\
\hline DIVERSITYXCATHOLIC & & & -0.0033 & -0.26 & & \\
\hline DIVERSITYXPROTESTANTISM & & & & & $0.0114 *$ & 1.80 \\
\hline SIZE & $0.0097 *$ & 1.94 & $0.0103 *$ & 2.02 & $0.0102 *$ & 2.03 \\
\hline LEV & $-0.0584^{* * *}$ & -20.83 & $-0.0587 * * *$ & -20.62 & $-0.0585^{* * *}$ & -20.64 \\
\hline $\mathrm{ROA}$ & $-0.1456^{* * *}$ & -4.06 & $-0.1496^{* * *}$ & -4.11 & $-0.1456^{* * *}$ & -4.02 \\
\hline $\mathrm{CFO}$ & $0.7235^{* * *}$ & 24.75 & $0.7250^{* * *}$ & 24.45 & $0.7217^{* * *}$ & 24.41 \\
\hline EMP & -0.0001 & -0.76 & -0.0002 & -0.96 & -0.0002 & -0.90 \\
\hline EXPORT & 0.0001 & 1.16 & 0.0001 & 0.94 & 0.0001 & 0.88 \\
\hline LARGE & $-0.0004 *$ & -1.92 & $-0.0003^{*}$ & -1.67 & $-0.0004 *$ & -1.76 \\
\hline BIG4 & 0.0009 & 0.11 & -0.0012 & -0.16 & -0.0012 & -0.15 \\
\hline$\Sigma$ YEAR & \multicolumn{2}{|c|}{ Included } & \multicolumn{2}{|c|}{ Included } & \multicolumn{2}{|c|}{ Included } \\
\hline$\Sigma I N D$ & \multicolumn{2}{|c|}{ Included } & \multicolumn{2}{|c|}{ Included } & \multicolumn{2}{|c|}{ Included } \\
\hline _cons & $-0.2546^{* *}$ & -2.04 & $-0.2663 * *$ & -2.10 & $-0.2627^{* *}$ & -2.08 \\
\hline Obs. & \multicolumn{6}{|c|}{1935} \\
\hline F-stat. & \multicolumn{2}{|c|}{$563.47^{* * *}$} & \multicolumn{2}{|c|}{$546.63^{* * *}$} & \multicolumn{2}{|c|}{$552.36^{* * *}$} \\
\hline Adj. $R^{2}$ & \multicolumn{2}{|c|}{0.9443} & \multicolumn{2}{|c|}{0.9426} & \multicolumn{2}{|c|}{0.9432} \\
\hline
\end{tabular}

Note $1:{ }^{*}{ }^{* *}$, and ${ }^{* * *}$ indicate significance at the $10 \%, 5 \%$, and $1 \%$ levels, respectively, for a two-tailed test. Note 2 : The definitions of variables are the same as the measurement of variables in Equation (1).

First, as presented by the Buddhism column of Table 4, DIVERSITY has a coefficient of 0.0083 $(p<0.01)$ at a significant level, whereas the interaction term of DIVERSITY and Buddhism has a coefficient of $-0.0272(p<0.01)$ at a significant level. These results provide empirical implications that the level of tax avoidance may be higher in a firm where the board members' religions are diverse. However, this tax avoidance activity may be weaker if the CEO follows Buddhism, thereby holding the diversity of the board members' religions.

Second, in the Catholic column of Table 4, DIVERSITY also has a statistically significant positive coefficient of $0.0051(p<0.1)$. These test results support a finding that the higher level of tax avoidance is expected in a firm where directors with different religious backgrounds serve on the BOD. On the other hand, the interaction variable of DIVERSITY and CATHOLIC shows an insignificant coefficient. This means that there is no statistically significant difference in the relationship between religious diversity and tax avoidance depending on whether the CEO's religion is Catholic. Thus, this may provide an implication that this tax avoidance phenomenon may not be affected when the CEO's religion is Catholicism. 
Third, as presented by the Protestantism column of Table 4, DIVERSITY shows a coefficient of 0.0015 $(p<0.1)$ at a significant level. In addition, the interaction term of DIVERSITY and PROTESTANTISM shows a coefficient of $0.0114(p<0.1)$ at a significant level. These results continue to hold that the level of tax avoidance may be higher in a firm where the board members' religions are diverse. Furthermore, if the CEO's religion is Protestantism, this tax avoidance phenomenon may be stronger.

The difference in the coefficients of the interaction terms of the CEO's religion, which have different coefficients that depend on the type of religion, is unclear. On the one hand, the inconsistency in the sign of the interaction term suggests that the BOD is likely to fail to provide a proper oversight on the tax avoidance of corporate management when the religious diversity of the BOD increases. On the other hand, CEOs have different levels of optimal tax avoidance depending on the religion they follow.

The control variables obtained results that are nearly similar to the test results presented in Table 3, except for the LARGE variable. LARGE has a statistically significant negative coefficient, as shown in Table 4, implying that the level of corporate tax avoidance is lower if the shareholding owned by the largest shareholder is high.

Table 5 provides the OLS regression results on the pattern of corporate tax avoidance in case of religious concentration wherein the religions of the board members are the same. As indicated in the Pooled Sample column of Table 5, CONCENTR has a statistic coefficient of $-0.0167(p<0.05)$ at a significant level. This result provides empirical evidence that the corporate tax avoidance may be reduced if the board members' religions are the same. This finding provides implications that the management's tax avoidance attempt may be discouraged by the BOD when all of the board members' religions are the same.

Table 5. The effects of directors' religious concentration on tax avoidance of firms.

\begin{tabular}{|c|c|c|c|c|c|c|c|c|}
\hline \multicolumn{9}{|c|}{$\begin{array}{c}\text { TAX AVOID }=\alpha_{0}+\beta_{1} C O N C E N T R+\beta_{2} S I Z E+\beta_{3} L E V+\beta_{4} R O A+\beta_{5} C F O+\beta_{6} E M P+\beta_{7} E X P O R T \\
+\beta_{8} L A R G E+\beta_{9} B I G 4+Y E A R+I N D+\varepsilon\end{array}$} \\
\hline & \multicolumn{2}{|c|}{ Pooled Sample } & \multicolumn{2}{|c|}{ Buddhism } & \multicolumn{2}{|c|}{ Catholic } & \multicolumn{2}{|c|}{ Protestantism } \\
\hline & Coeff. & $t$-stat. & Coeff. & $t$-stat. & Coeff. & $t$-stat. & Coeff. & $t$-stat. \\
\hline CON-CENTR & -0.0167 ** & -2.20 & $-0.0011^{* * *}$ & -2.53 & -0.0099 & -0.84 & $-0.0140 *$ & -1.70 \\
\hline SIZE & $0.0105 *$ & 2.08 & $0.0104^{* *}$ & 2.04 & $0.0104^{* *}$ & 2.04 & $0.0101 *$ & 1.99 \\
\hline LEV & $-0.0589^{* * *}$ & -20.78 & $-0.0586^{* * *}$ & -20.51 & $-0.0587^{* * *}$ & -20.58 & $-0.0585^{* * *}$ & -20.61 \\
\hline ROA & $-0.1480^{* * *}$ & -4.09 & $-0.1477^{* * * *}$ & -4.05 & $-0.1479 * * *$ & -4.06 & $-0.1451^{* * *}$ & -3.99 \\
\hline $\mathrm{CFO}$ & $0.7181^{* * *}$ & 24.35 & $0.7214^{* * * *}$ & 24.30 & $0.7217^{* * *}$ & 24.35 & $0.7196^{* * *}$ & 24.35 \\
\hline EMP & -0.0002 & -0.91 & -0.0002 & -0.95 & -0.0002 & -1.00 & -0.0002 & -0.85 \\
\hline EXPORT & 0.0001 & 1.01 & 0.0001 & 0.96 & 0.0001 & 1.01 & 0.0001 & 0.89 \\
\hline LARGE & -0.0003 & -1.46 & -0.0003 & -1.49 & -0.0003 & -1.49 & -0.0003 & -1.56 \\
\hline BIG4 & 0.0006 & 0.08 & 0.0006 & 0.08 & -0.0002 & -0.02 & 0.0015 & 0.20 \\
\hline$\Sigma$ YEAR & \multicolumn{2}{|c|}{ Included } & \multicolumn{2}{|c|}{ Included } & \multicolumn{2}{|c|}{ Included } & \multicolumn{2}{|c|}{ Included } \\
\hline$\Sigma I N D$ & \multicolumn{2}{|c|}{ Included } & \multicolumn{2}{|c|}{ Included } & \multicolumn{2}{|c|}{ Included } & \multicolumn{2}{|c|}{ Included } \\
\hline _cons & $-0.2625^{* *}$ & -2.08 & $-0.2692 * *$ & -2.12 & $-0.2677^{* *}$ & -2.11 & $-0.2580^{* *}$ & -2.04 \\
\hline Obs. & \multicolumn{8}{|c|}{1935} \\
\hline F-stat. & \multirow{2}{*}{\multicolumn{2}{|c|}{$\begin{array}{c}612.83 * * * \\
0.9431\end{array}$}} & \multicolumn{2}{|c|}{$603.24^{* * *}$} & \multicolumn{2}{|c|}{$604.60^{* * *}$} & \multicolumn{2}{|c|}{$608.96^{* * *}$} \\
\hline Adj. $R^{2}$ & & & \multicolumn{2}{|c|}{0.9423} & \multicolumn{2}{|c|}{0.9424} & \multicolumn{2}{|c|}{0.9428} \\
\hline
\end{tabular}

Note $1:{ }^{*}, * *$, and ${ }^{* * *}$ indicate significance at the $10 \%, 5 \%$, and $1 \%$ levels, respectively, for a two-tailed test. Note 2 : Definition of CONCENTR is 1 if all directors' religions are same, 0 otherwise. The definitions of other variables are the same as the measurement of variables in Equation (1).

In particular, in the columns of Buddhism and Protestantism, CONCENTR shows a statistical negative coefficient of $-0.0011(p<0.01)$ and $-0.0140(p<0.1)$ at a significant level, respectively. This finding means that the level of tax avoidance may be lower in a corporation where the religion of board members are converged into either Buddhism or Protestantism. This finding supports that a corporation where all of the religions of the board members are concentrated on a single religion makes less attempts to undertake tax avoidance transactions.

Control variables, such as SIZE and CFO, have statistically significant positive coefficients, implying that a corporation with large size or high cash flow from operations tends to be engaged in more tax avoidance. Control variables, such as LEV and ROA, have negative correlation with TAX 
AVOID at a statistically significant level. This finding implies that firms with low financial leverage or ROA may be engaged in several tax avoidances.

The endogeneity problem may potentially be involved in analyzing firms that involve board members with diverse religions compared with other firms. To address the endogeneity issue, the Heckman two-stage model is used, and the hypotheses are retested (Heckman 1979). Under the Heckman two-stage model, the inverse Mills ratio (IMR) is obtained at the first stage by using the probit model, and the test results are reanalyzed at the second stage after putting the IMR in the regression model (Srinidhi et al. 2011; Jeon et al. 2017). Even in a test where the Heckman two-stage model is utilized, results similar to the test provided in Tables $3-5$ were obtained. Therefore, no endogeneity problems were encountered in the previously conducted tests.

\section{Conclusions}

In this study, we empirically investigated how the diversity of the directors' religion is linked to the tax avoidance activities of firms. Previous studies provide empirical evidence that the diversity of the BOD, such as their educational background, majors, gender, and nationality, can alleviate the manager's agency problem and direct management decisions to maximize the firm's value. However, studies on the religious diversity of the BOD at the corporate level have not been actively conducted yet. Meanwhile, some studies show that tax avoidance is less likely to happen because an individual religious belief is stronger or because religiosity reduces tax avoidance attempts. In this regard, our study was motivated to investigate whether the religious diversity of the BOD plays a role in monitoring the management's tax avoidance activity given that one of the board's responsibilities is to provide an oversight on the management's behavior.

Our statistical findings are summarized as follows. First, our empirical results show that the religious diversity in the BOD has a positive relation with the level of corporate tax avoidance. The test results support that the level of corporate tax avoidance is high when the religious diversity in BOD is high. There appears to be a positive correlation between high BOD religious diversity and tax avoidance in a corporate management style.

Second, tax avoidance tends to happen in a company where the religions of board members are diverse. However, this tendency would vary depending upon which religion the CEO follows. This phenomenon suggests that the corporate tax avoidance tends to be related to the CEO's religion. Furthermore, this would be in context with prior research (Desai et al. 2007; Law and Mills 2017).

Third, the religious concentration has a negative relationship with the corporate tax avoidance. Corporate tax avoidance may be reduced if the religions of the board members are the same. The management's tax avoidance may be discouraged when BOD members' religions are the same. Therefore, one could argue there is a likelihood that the religious concentration in the BOD may actually reduce tax avoidance.

The results of this study make an implication that the tax avoidance tendency of the firm is in accordance with the degree of religious diversity of the board directors rather than presenting the relationship between a specific religion and tax avoidance.

This study contributes to the literature by providing empirical evidence that the religious diversity of the BOD may potentially affect the tax avoidance attitude of corporate management. In contrast to prior research, the diversity of the BOD's religion is addressed in this study for the first time.

However, our study is subject to limitations. Our findings suggest that tax avoidance would vary depending on the type of religion the CEO follows. However, it is not clear that there is a causal relationship between the type of religion and tax avoidance. We acknowledge these limitations and inform readers that our results should be subject to future research.

Author Contributions: Conceptualization, S.M.Y. and H.T.C.; methodology, S.M.Y. and H.T.C.; software, S.M.Y. and H.T.C.; validation, S.M.Y. and H.T.C.; investigation, S.M.Y. and H.T.C.; resources, H.T.C.; writing-original draft preparation, H.T.C.; writing—review and editing, S.M.Y.; project administration, S.M.Y. and H.T.C. All authors have read and agreed to the published version of the manuscript. 
Funding: This study was supported by the Research Program funded by the Seoul National University of Science and Technology (2020-0437).

Conflicts of Interest: The authors declare no conflict of interest.

\section{References}

Adams, Renee B., and Daniel Ferreira. 2009. Women in the boardroom and their impact on governance and performance. Journal of Financial Economics 94: 291-309. [CrossRef]

Armstrong, Christopher S., Jennifer L. Blouin, Alan D. Jagolinzer, and David F. Larcker. 2015. Corporate Governance, Incentives, and Tax Avoidance. Journal of Accounting and Economics 60: 1-17. [CrossRef]

Beasley, Mark. S. 1996. An empirical analysis of the relation between the board of director composition and financial statement fraud. The Accounting Review 71: 443-65.

Bhagat, Sanjai, and Brian Bolton. 2008. Corporate governance and firm performance. Journal of Corporate Finance 14: 257-73. [CrossRef]

Carter, David A., Betty J. Simkins, and W. Gary Simpson. 2003. Corporate governance, board diversity, and firm value. Financial Review 38: 33-53. [CrossRef]

Charreaux, Gerard, and Philippe Desbrières. 1998. Gouvernance des entreprises: Valeur partenariale contre valeur actionnariale. Finance Contrôle Stratégie 1: 57-88.

Chen, Kevin C., Zhihong Chen, and K. C. John Wei. 2009. Legal protection of investors, corporate governance, and the cost of equity capital. Journal of Corporate Finance 15: 273-89. [CrossRef]

Choi, Ki Ho. 2018. Review of Empirical Tax Research on Tax Avoidance. Korean Journal of Tax Research 35: 207-75.

Dechow, Patricia M., Richard. G. Sloan, and Amy P. Sweeney. 1996. Causes and consequences of earnings manipulation: An analysis of firms subject to enforcement actions by the SEC. Contemporary Accounting Research 13: 1-36. [CrossRef]

Desai, Mihir A., and Dhammika Dharmapala. 2006. Corporate Tax avoidance and High-powered Incentives. Journal of Financial Economics 79: 145-79. [CrossRef]

Desai, Mihir A., Alexander Dyck, and Luigi Zingales. 2007. Theft and taxes. Journal of Financial Economics 84: 591-623. [CrossRef]

Fan, Joseph P. H., T. J. Wong, and Tianyu Zhang. 2007. Politically connected CEOs, corporate governance, and Post-IPO performance of China's newly partially privatized firms. Journal of Financial Economics 84: 330-57. [CrossRef]

Goldman, Eitan, Jorg Rocholl, and Jongil So. 2009. Do politically connected boards affect firm value? Review of Financial Studies 22: 2331-60. [CrossRef]

Gul, Ferdinand A., Bin Srinidhi, and Anthony C. Ng. 2011. Does board gender diversity improve the informativeness of stock prices? Journal of Accounting and Economics 51: 314-38. [CrossRef]

Gupta, Ranjana, and Robert McGee. 2010. Study on Tax Evasion Perceptions in Australasia. Australian Tax Forum 25: 507-34.

Heckman, James J. 1979. Sample selection bias as a specification error. Econometrica 47: 153-61. [CrossRef]

Hernández-Nicolás, Carmen María, Juan Francisco Martín-Ugedo, and Antonio Mínguez-Vera. 2019. Agricultural cooperatives on returns and debt: An empirical analysis. Agribusiness 35: 639-56. [CrossRef]

Jeon, Kyeongmin, Shin Youngzik, and Kim Hyunpyo. 2017. Board Diversity and Real Earnings Management. Korean Journal of Accounting 26: 33-77.

Jun, Byung Wook, and Sung Man Yoon. 2018. Taxpayer's Religiosity, Religion, and the Perceptions of Tax Equity: Case of South Korea. Religions 9: 333. [CrossRef]

Kim, Byoung Ho. 2006. The Influence of the Board Composition on Earnings Management in Korean Firms: Looking at Cases of Upwards and Downwards Management. Korean Accounting Review 31: 1-32.

Kim, Jeong Ok, and Gil Soo Bae. 2007. Corporate Governance and Accounting Conservatism: Evidence from Board and Audit Committee Characteristics. Korean Accounting Review 32: 89-115.

Klein, April. 2002. Audit committee, board of director characteristics, and earnings management. Journal of Accounting and Economics 33: 375-400. [CrossRef]

Law, Kelvin, K. F, and Lillian F. Mills. 2017. Military experience and corporate tax avoidance. Review of Accounting Studies 22: 141-84. [CrossRef] 
Matten, Dirk, and Andrew Crane. 2005. Corporate citizenship: Toward an extended theoretical conceptualization. Academy of Management Review 30: 166-79. [CrossRef]

Rego, Sonja Olhoft, and Ryan Wilson. 2012. Equity Risk Incentives and Corporate Tax Aggressiveness. Journal of Accounting Research 50: 775-810. [CrossRef]

Ross, Adriana M., and Robert W. McGee. 2011. Attitudes toward Tax Evasion: A Demographic Study of Switzerland. Business Studies Journal 3: 1-47.

Shehata, Nermeen, Ahmed Salhin, and Moataz El-Helaly. 2017. Board diversity and firm performance: Evidence from the U.K. SMEs. Applied Economics 49: 4817-32. [CrossRef]

Srinidhi, Bin, Ferdinand A. Gul, and Judy Tsui. 2011. Female Directors and Earnings Quality. Contemporary Accounting Research 28: 1610-44. [CrossRef]

Wang, Lihong. 2015. Protection or expropriation: Politically connected independent directors in China. Journal of Banking \& Finance 55: 92-106.

$\mathrm{Wu}$, Wenfeng, Chongfeng Wu, Chunyang Zhou, and Jun Wu. 2012. Political connections, tax benefits and firm performance: Evidence from China. Journal of Accounting and Public Policy 31: 277-300. [CrossRef]

Xie, Biao, Wallace N. Davidson, and Peter J. DaDalt. 2003. Earnings management and corporate governance: The role of the board and the audit committee. Journal of Corporate Finance 9: 295-316. [CrossRef]

(C) 2020 by the authors. Licensee MDPI, Basel, Switzerland. This article is an open access article distributed under the terms and conditions of the Creative Commons Attribution (CC BY) license (http://creativecommons.org/licenses/by/4.0/). 